Supporting Information for:

Polymorphism of the Signaling Molecule c-di-GMP

Zhaoying Zhang, Seho Kim, Barbara L. Gaffney, and Roger A. Jones*

Department of Chemistry and Chemical Biology, 610 Taylor Road, Rutgers, The State University of New Jersey, Piscataway, New Jersey 08854

Table of Contents:

1. Synthesis of c-GMP-IMP, 2

S2

2. Synthesis of Oligoethylene Oxide Tethered c-di-GMP, 3a and 3b

S4

3. First Derivative Curves of UV Melts

S6

4. Full UV Spectra for c-di-GMP

S7

5. Translational Diffusion Rates for c-di-GMP with $\mathrm{K}^{+}$and with $\mathrm{Li}^{+}$

S8

6. ${ }^{1} \mathrm{H} \&{ }^{31}$ P NMR of c-IMP-GMP, 2

S9

7. ${ }^{1} \mathrm{H} \&{ }^{31} \mathrm{P}$ NMR of Oligoethylene Oxide Tethered c-di-GMP, 3a

S10

8. Full 1D ${ }^{1} \mathrm{H}$ NMR of $\mathrm{c}$-di-GMP, $1, \mathrm{Li}^{+}$

S11

9. Full 1D ${ }^{1} \mathrm{H}$ NMR of c-GMP-IMP, 2, $\mathrm{Li}^{+}$

S12

10. Full 1D ${ }^{1} \mathrm{H}$ NMR of tethered c-di-GMP, 3a, $\mathrm{Li}^{+}$

S13 


\section{Synthesis of c-GMP-IMP, 2}

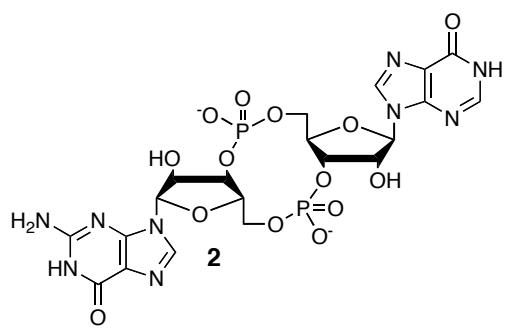

\section{Protected Inosine ${ }^{1}$}

Inosine $(6.7 \mathrm{~g}, 25 \mathrm{mmol})$ was dried by coevaporation with pyridine and reacted with $13.5 \mathrm{~mL}$ (35 mmol, $1.4 \mathrm{eq}$ ) of di-tert-butylsilyl ditriflate in $50 \mathrm{~mL} \mathrm{DMF}$ in an ice bath for $0.5 \mathrm{hr}$ to introduce a cyclic silylene at the $3^{\prime}$ and 5' hydroxyls. This was followed immediately by addition of $8.51 \mathrm{~g}(125 \mathrm{mmol}, 5 \mathrm{eq})$ of imidazole, and the reaction was stirred at room temperature for $0.5 \mathrm{hr}$. Then $4.53 \mathrm{~g}$ (30 mmol, $1.2 \mathrm{eq})$ of tert-butyldimethylchlorosilane was added to introduce the TBS group at the 2 ' hydroxyl. The reaction was stirred for $2.5 \mathrm{hr}$ in a $60^{\circ} \mathrm{C}$ water bath and then quenched with saturated $\mathrm{NaHCO}_{3}$ solution. The mixture was extracted with 2x100 mL portions of ethyl acetate. The combined organic layers were washed with 2x100 mL 4\% $\mathrm{NaHCO}_{3}$ solution and then concentrated to dryness. The product was purified by silica gel

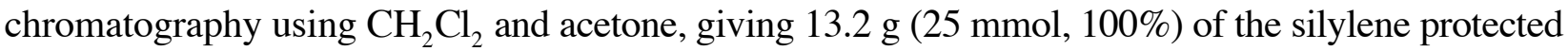
inosine. HF.pyridine ( $1 \mathrm{~mL}, 3.2 \mathrm{eq}$ ), diluted with $5 \mathrm{~mL}$ additional pyridine, was added to a suspension of $5.23 \mathrm{~g}(10 \mathrm{mmol})$ of the silylene protected inosine in $200 \mathrm{~mL}$ dry ethyl acetate, and the reaction was stirred for $3 \mathrm{hr}$ in an ice bath to remove the silylene group. After $3 \mathrm{hr}$, saturated $\mathrm{NaHCO}_{3}$ solution was used to wash the mixture, and the organic layer was then concentrated to a small volume and dried by coevaporation with pyridine. Dimethoxytrityl chloride $(3.56 \mathrm{~g}, 10.5 \mathrm{mmol}, 1.05 \mathrm{eq})$ was then added to introduce the DMT group at the 5' hydroxyl. The product was purified twice by precipitation in $200 \mathrm{~mL}$ hexane. After drying in a desiccator over $\mathrm{P}_{2} \mathrm{O}_{5}$ overnight, $5.1 \mathrm{~g}(7.46 \mathrm{mmol}, 75 \%$ from inosine $)$ of protected inosine was obtained.

\section{Linear GMP-IMP}

The protected inosine described above $(5.1 \mathrm{~g}, 7.43 \mathrm{mmol})$ in $20 \mathrm{~mL}$ dry $\mathrm{CH}_{2} \mathrm{Cl}_{2}$ was reacted with $3.2 \mathrm{~mL}$ 
(11.1 mmol, $1.5 \mathrm{eq})$ of bis(diisopropylamino)methyl phosphoramidite, catalyzed by $2.15 \mathrm{~g}$ (11.1 mmol, 1.5 eq) of pyridinium trifluoroacetate at room temperature for $1 \mathrm{hr}$ to form the methylphosphoramidite, which was then purified by silica gel chromatography using $\mathrm{CH}_{2} \mathrm{Cl}_{2}$ and hexane to give $5.0 \mathrm{~g}(5.89 \mathrm{mmol}, 80 \%)$ of the inosine phosphoramidite.

This phosphoramidite $(2.62 \mathrm{~g}, 3.10 \mathrm{mmol}, 2.2 \mathrm{eq})$ was coupled with $0.86 \mathrm{~g}(1.41 \mathrm{mmol})$ of $N$ isobutyryl-2'-tertbutyldimethylsilyl-3'-H-phosphonate-guanosine ${ }^{2}$ in dry $\mathrm{CH}_{3} \mathrm{CN}$ at room temperature for $30 \mathrm{~min}$, activated by $1.18 \mathrm{~g}$ (2.2 eq) of pyridinium trifluroacetate, to form the internucleotide phosphite linkage. This coupling was immediately followed by oxidation with $1.46 \mathrm{~mL}(10.5 \mathrm{mmol}, 7.5 \mathrm{eq})$ of tertbutylhydroperoxide to form the linear dimer, which was then concentrated, dissolved in $100 \mathrm{~mL}$ ethyl acetate and washed with saturated $\mathrm{NaHCO}_{3}$ solution. The crude product was purified by silica gel chromatography using ethyl acetate $(0.5 \%$ pyridine $)$ and methanol.

This linear dimer was then detritylated by vortexing with $15 \mathrm{~mL}$ Amberlite IR-120 Plus sulfonic acid resin, followed by purification by precipitation in ethyl ether to give $0.82 \mathrm{~g}(0.83 \mathrm{mmol}, 59 \%$ from the $\mathrm{H}$ phosphonate) of the linear dimer with a free $5^{\prime} \mathrm{OH}$.

c-GMP-IMP

The linear dimer above $(0.82 \mathrm{~g}, 0.83 \mathrm{mmol})$ in $80 \mathrm{~mL}$ dry pyridine was cyclized by stirring with $1.65 \mathrm{~g}$ (8.3 mmol, $10 \mathrm{eq}$ ) of adamantanecarbonyl chloride for $2 \mathrm{~min}$ at room temperature, followed by addition of $15 \mathrm{~mL}$ methanol. N-bromosuccinimide (NBS) (0.96 g, $5.19 \mathrm{mmol}, 6.25 \mathrm{eq})$ was added to oxidize the phosphite linkage and introduce methyl protection at the $2^{\text {nd }}$ phosphate. The reaction mixture was quenched with $1 \mathrm{M}$ phosphate buffer, $\mathrm{pH} 7.0$, containing $1 \% \mathrm{Na}_{2} \mathrm{SO}_{3}$ to remove excess NBS, and then extracted with $2 \times 50 \mathrm{~mL}$ ethyl acetate. The organic layers were concentrated to a small volume and the product precipitated in $50 \mathrm{~mL}$ hexane. The product was purified by silica gel chromatography using ethyl acetate and methanol to give $0.57 \mathrm{~g}(0.57 \mathrm{mmol}, 69 \%)$ of the protected c-GMP-IMP.

The protected dimer $(0.22 \mathrm{~g}, 0.22 \mathrm{mmol})$ was treated with a mixture of $5 \mathrm{~mL}$ pyridine and $5 \mathrm{~mL}$ concentrated aq $\mathrm{NH}_{3}$ for 2 days at room temperature to remove the isobutyryl protecting group and the methyl phosphate protecting group. The product was then treated with $125 \mathrm{eq}$ of TEA $\cdot \mathrm{HF}$ with $1.5 \mathrm{~mL}$ additional TEA to remove the TBS group. The crude product 2 was purified by reversed phase 
chromatography using $0.1 \mathrm{M}$ triethylammonium acetate (TEAA) and $\mathrm{CH}_{3} \mathrm{CN}$. Fractions containing pure product were lyophilized and desalted by reversed phase chromatography using $0.1 \mathrm{M}$ ammonium bicarbonate and $\mathrm{CH}_{3} \mathrm{CN}$. Fractions containing pure product were combined and lyophilized to give $0.066 \mathrm{~g}$ ( $0.098 \mathrm{mmol}, 45 \%$ from protected $\mathbf{2})$ of the ammonium form of $\mathbf{2}$. The identity of 2 was confirmed by ESILCMS in negative mode, showing $m / z$ (M-1) 674.26 (calcd for $\mathrm{C}_{20} \mathrm{H}_{23} \mathrm{~N}_{9} \mathrm{O}_{14} \mathrm{P}_{2}$ : 674.08). Different salt forms were obtained by ion exchange using columns $(5 \mathrm{~mL})$ of AG $50 \mathrm{~W}-\mathrm{X} 2$ sulfonic acid resin previously converted to the appropriate cation forms. The extinction coefficient was determined to be $19,400 \mathrm{OD} \mathrm{M}^{-1}$ $\mathrm{cm}^{-1} .^{2}$

\section{Synthesis of Oligoethylene Oxide Tethered c-di-GMP, 3a and 3b}

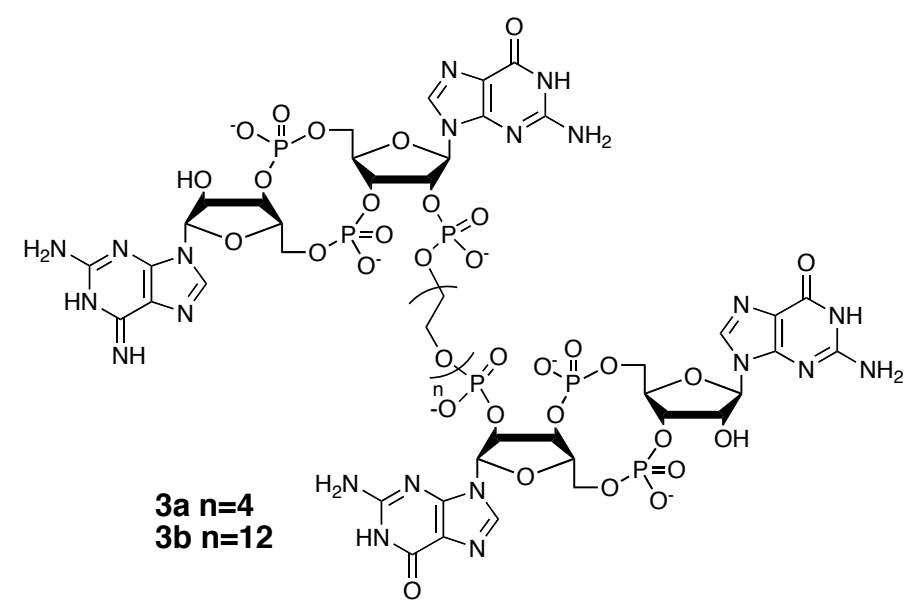

Mono-desilylated intermediate

c-di-GMP, $1(0.90 \mathrm{~g}, 0.83 \mathrm{mmol})$ was dissolved in $20 \mathrm{~mL} \mathrm{CH}_{3} \mathrm{CN}$ in a $50 \mathrm{~mL}$ plastic tube and then treated with $0.2 \mathrm{~mL}(7.7 \mathrm{mmol}, 9.3 \mathrm{eq})$ pyridine $\mathrm{HF}$. The reaction mixture was stirred at room temperature for $7 \mathrm{hr}$ and then poured into $200 \mathrm{~mL} \mathrm{CH}_{2} \mathrm{Cl}_{2}$. It was washed 3x with $150 \mathrm{~mL}$ phosphate buffer, $\mathrm{pH}$ 7.3. After concentration of the organic layer, the product was purified by silica gel column chromatography to give $0.35 \mathrm{~g}(0.32 \mathrm{mmol})$ of recovered starting material and $0.2 \mathrm{~g}(0.21 \mathrm{mmol}, 41 \%)$ of the mono-desilylated intermediate. Its identity was confirmed by ESI-LCMS in negative mode, showing $\mathrm{m} / \mathrm{z}$ (M-1) 971.25 (calcd for $\mathrm{C}_{36} \mathrm{H}_{53} \mathrm{~N}_{10} \mathrm{O}_{16} \mathrm{P}_{2} \mathrm{Si}$ : 971.29).

Tetraethylene Oxide Tethered c-di-GMP, $3 a$ 
Pyridinium trifluoroacetate $(0.17 \mathrm{~g}, 0.91 \mathrm{mmol}, 2 \mathrm{eq})$ was dissolved in $0.63 \mathrm{~mL}$ dry $\mathrm{CH}_{3} \mathrm{CN}$ in a $5 \mathrm{~mL}$ flask. Cyanoethyldiisopropyl phosphoramidite $(0.29 \mathrm{~mL}, 0.91 \mathrm{mmol}, 2 \mathrm{eq})$ was added to the flask, followed by addition of $0.078 \mathrm{~mL}(0.45 \mathrm{mmol})$ tetraethyleneoxide. The mixture was stirred at room temperature for $1 \mathrm{hr}$. Then $0.1 \mathrm{~mL}(\sim 0.045 \mathrm{mmol}, 0.9 \mathrm{eq})$ of the reaction mixture was removed by syringe and added over 5 minutes to another $5 \mathrm{~mL}$ flask containing $0.097 \mathrm{~g}(0.1 \mathrm{mmol})$ of the mono-desilylated intermediate, $0.035 \mathrm{~g}(0.18 \mathrm{mmol}, 1.8 \mathrm{eq})$ of pyridinium trifluoroacetate and $0.25 \mathrm{~mL} \mathrm{CH}_{2} \mathrm{Cl}_{2}$. An additional $0.2 \mathrm{~mL}$ of the tetraethylene oxide phosphoramidite mixture was added over 10 min to ensure complete reaction, and the mixture was stirred for another $30 \mathrm{~min}$. Tert-butylhydroperoxide $(0.2 \mathrm{~mL}, 1.44$ mmol, 14.4 eq) was used to oxidize the phosphite linkages to phosphate linkages. After 20 min, the mixture was transferred to a larger flask and coevaporated with pyridine to remove excess tertbutylhydroperoxide. Pyridine/conc aq $\mathrm{NH}_{3}(1 / 1)(5 \mathrm{~mL})$ was added to the flask. After $2 \mathrm{~d}$, the mixture was concentrated and dried by evaporation with pyridine. TEA $3 \mathrm{HF}(0.7 \mathrm{~mL}, 12.7 \mathrm{mmol}, 127 \mathrm{eq})$ with $0.7 \mathrm{~mL}$ additional TEA was added, and the mixture was heated at $50{ }^{\circ} \mathrm{C}$ for $4 \mathrm{hr}$. The crude product was purified by semipreparative reversed phase $\mathrm{C} 18$ chromatography using $0.1 \mathrm{M}$ TEAA and $\mathrm{CH}_{3} \mathrm{CN}$. The pure fractions were lyophilized and desalted by reversed phase $\mathrm{C} 18$ chromatography using $0.1 \mathrm{M} \mathrm{NH}_{4} \mathrm{HCO}_{3}$ and $\mathrm{CH}_{3} \mathrm{CN}$ to give $0.036 \mathrm{~g}$ ( $0.02 \mathrm{mmol}, 40 \%$ from the mono-desilylated intermediate) of pure 3a. Its identity was confirmed by ESI-LCMS in negative mode, showing $\mathrm{m} / z$ (M-1) 1697.60 (calcd for $\mathrm{C}_{48} \mathrm{H}_{63} \mathrm{~N}_{20} \mathrm{O}_{37} \mathrm{P}_{6}$ : 1697.21). Different salt forms were obtained by ion exchange using columns (5 mL) of AG 50W-X2 sulfonic acid resin previously converted to the appropriate cation forms. The extinction coefficient of $\mathbf{3 a}$ was determined to be $48,700 \mathrm{OD} \mathrm{M}^{-1} \mathrm{~cm}^{-1}$.

\section{Dodecaethylene Oxide Tethered Dimer, $\mathbf{3 b}$}

Dodecaethyleneoxide $(0.25 \mathrm{~g}, 0.45 \mathrm{mmol})$ was placed in a $5 \mathrm{~mL}$ dry flask. Cyanoethyldiisopropyl phosphoramidite $(0.29 \mathrm{~mL}, 0.91 \mathrm{mmol}, 2 \mathrm{eq})$ was added to the flask followed by addition of $0.17 \mathrm{~g}(0.91$ mmol, 2 eq) of pyridinium trifluoroacetate dissolved in $0.7 \mathrm{~mL} \mathrm{CH}_{3} \mathrm{CN}$. The same procedure described above was followed to give $0.025 \mathrm{~g}(0.012 \mathrm{mmol}, 24 \%$ from the mono-desilylated intermediate $)$ of $\mathbf{3 b}$. Its identity was confirmed by ESI-LCMS in negative mode, showing $m / z$ (M-1) 2050.36 (calc for $\mathrm{C}_{64} \mathrm{H}_{95} \mathrm{~N}_{20} \mathrm{O}_{45} \mathrm{P}_{6}: 2049.42$ ). Its extinction coefficient was determined to be 48,200 OD M${ }^{-1} \mathrm{~cm}^{-1}$. 


\section{First Derivative Curves of UV Melts}
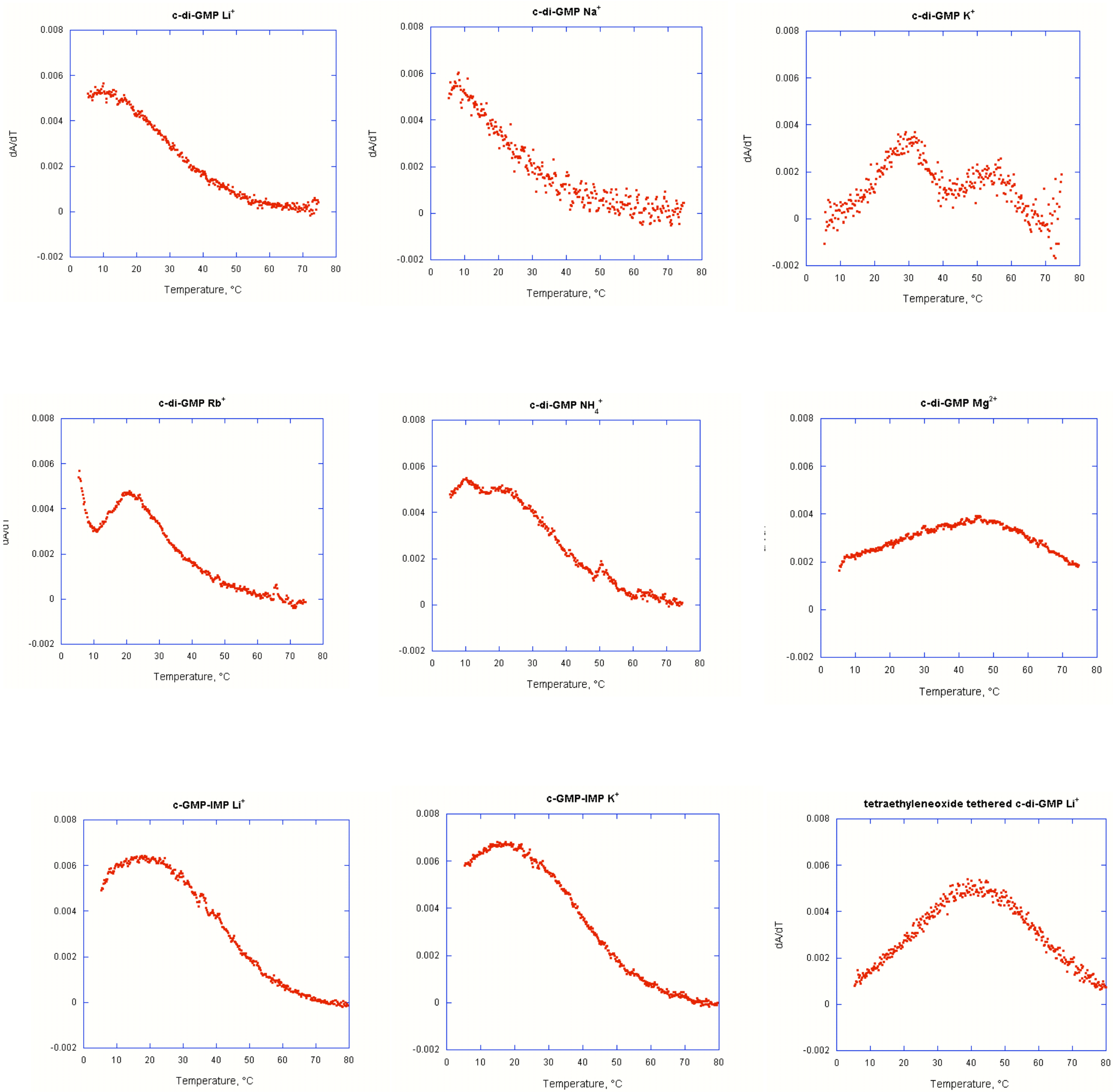

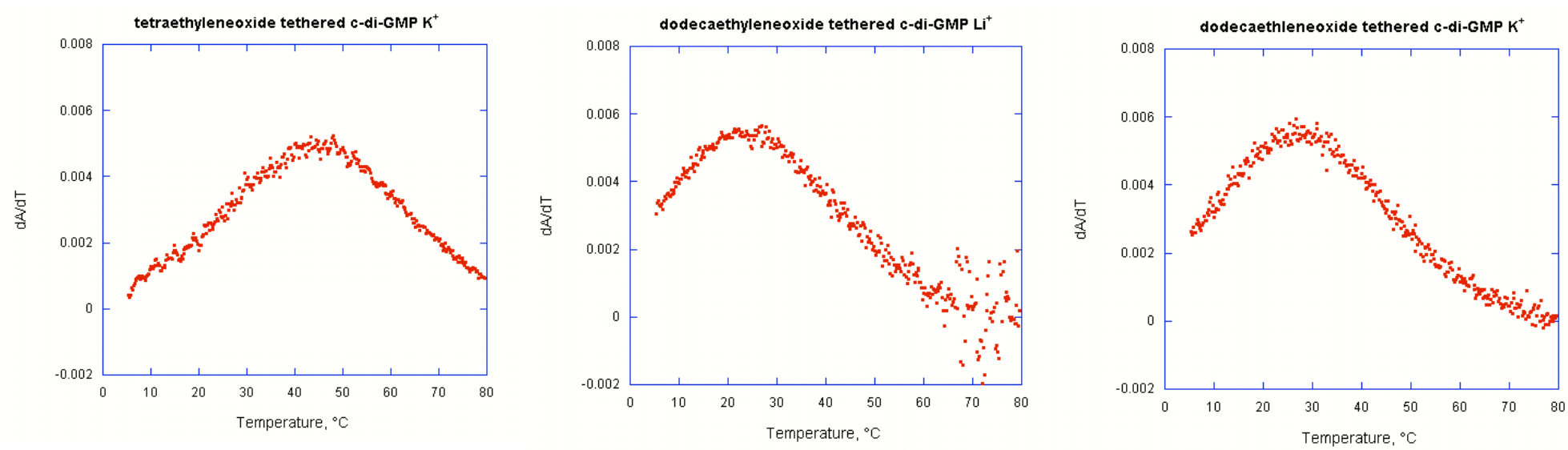

\section{UV Spectra of c-di-GMP, 1 , with different cations at $5^{\circ} \mathrm{C}$}

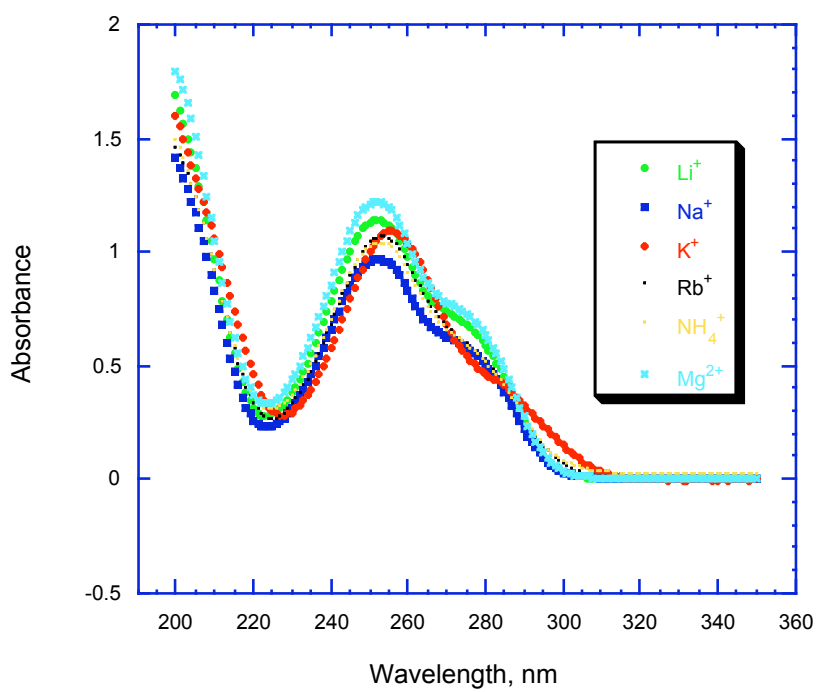



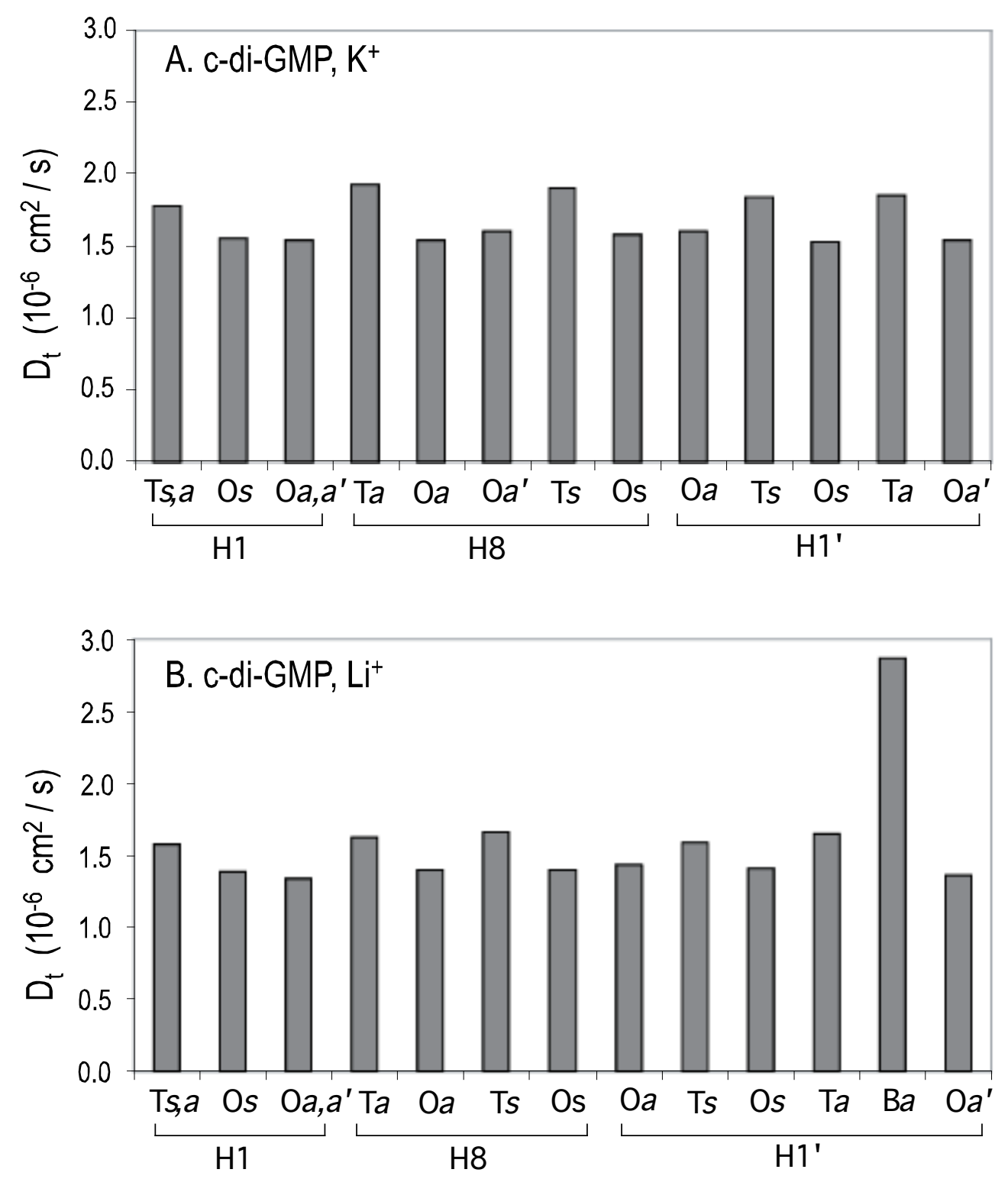


\section{6a. ${ }^{31}$ P NMR Spectra of c-GMP-IMP, 2}
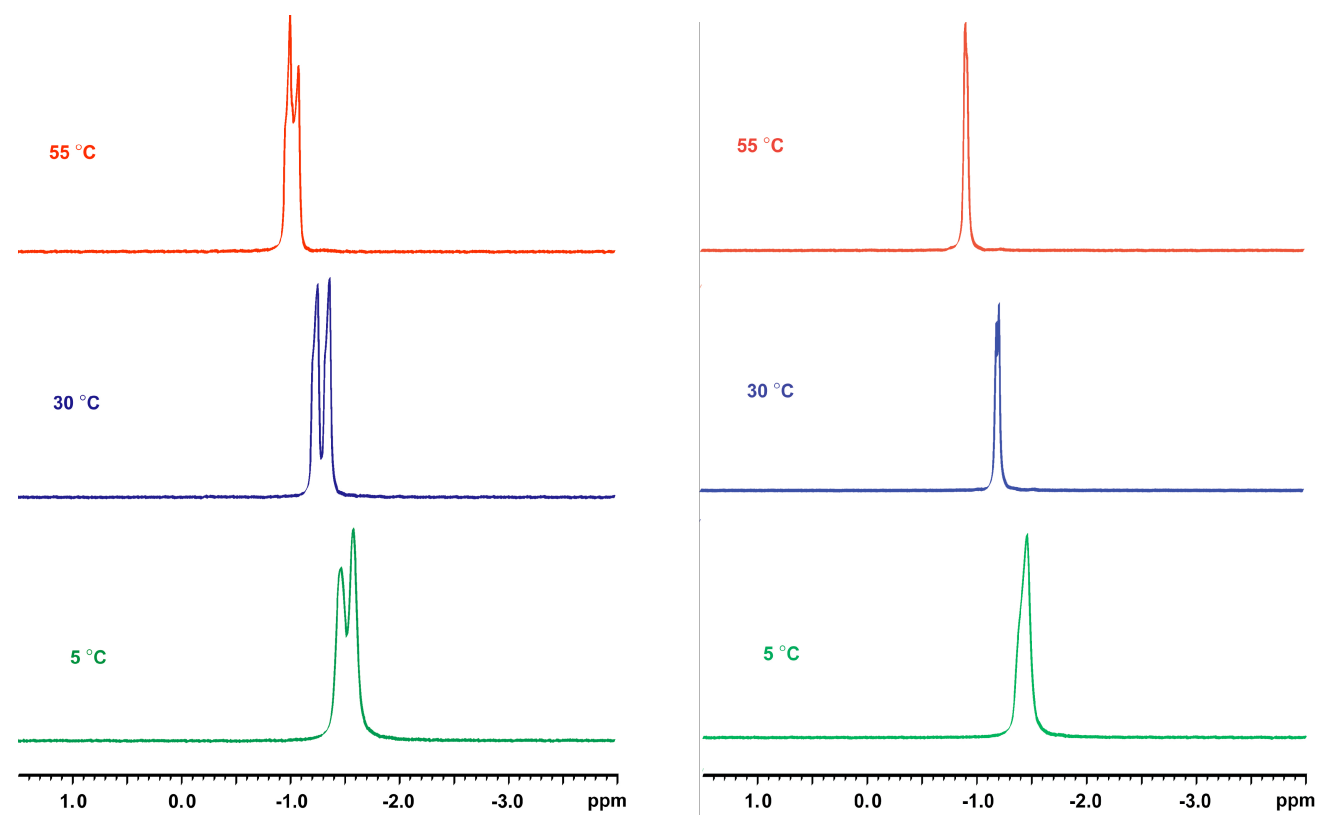

Left: $61.2 \mathrm{mM} 2$ in $0.1 \mathrm{M} \mathrm{LiCl}, 90 / 10 \mathrm{H}_{2} \mathrm{O} / \mathrm{D}_{2} \mathrm{O}$, pH 7; Right: $60.8 \mathrm{mM} 2$ in $0.1 \mathrm{M} \mathrm{KCl}, 90 / 10 \mathrm{H}_{2} \mathrm{O} / \mathrm{D}_{2} \mathrm{O}$ 6b. ${ }^{1} \mathrm{H}$ NMR Spectra of c-GMP-IMP, 2
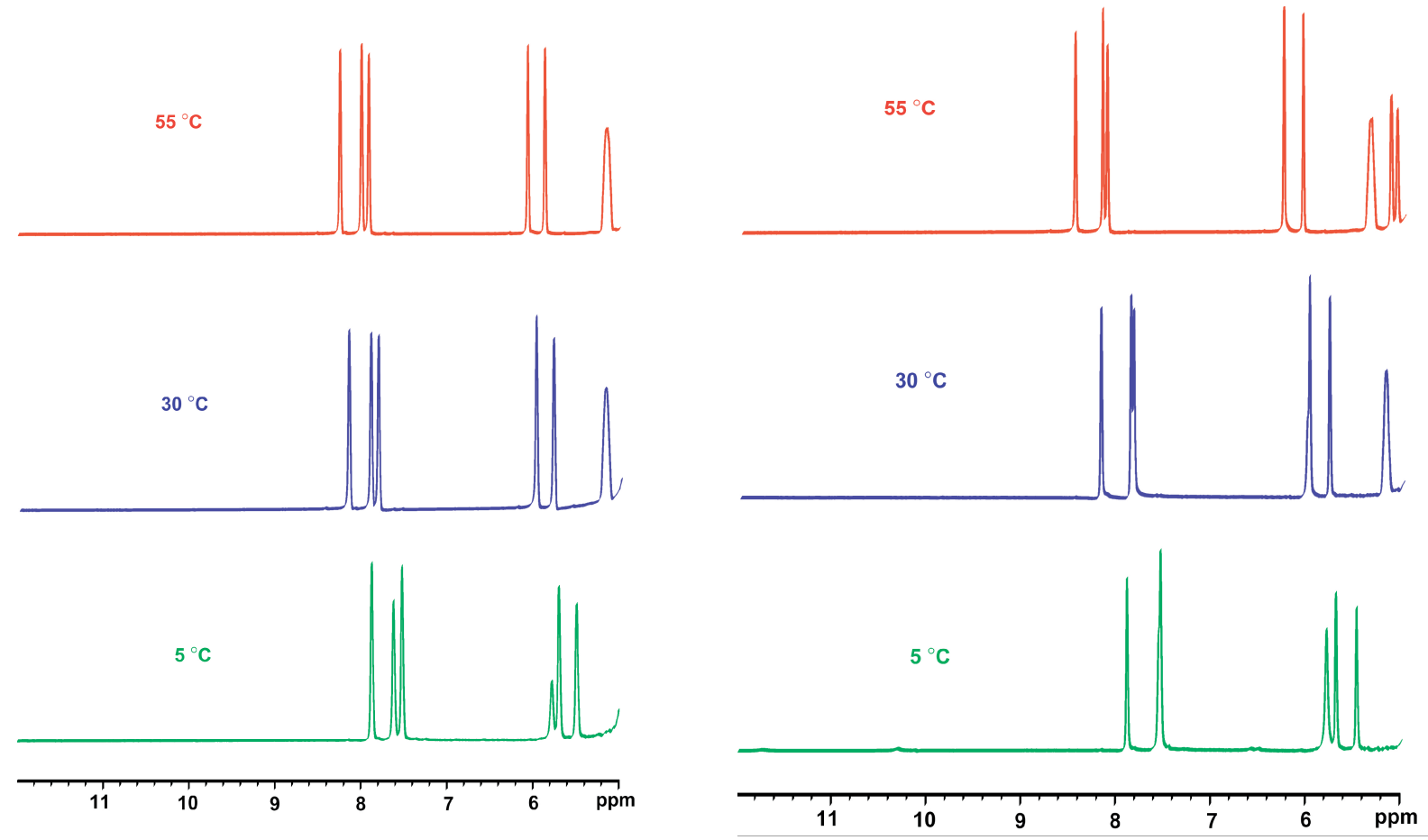

Left: $61.2 \mathrm{mM} 2$ in $0.1 \mathrm{M} \mathrm{LiCl}, 90 / 10 \mathrm{H}_{2} \mathrm{O} / \mathrm{D}_{2} \mathrm{O}$, pH 7; Right: $60.8 \mathrm{mM} 2$ in $0.1 \mathrm{M} \mathrm{KCl}, 90 / 10 \mathrm{H}_{2} \mathrm{O} / \mathrm{D}_{2} \mathrm{O}$ 
7a. ${ }^{31}$ P NMR Spectra of Oligoethylene Oxide Tethered c-di-GMP, 3a
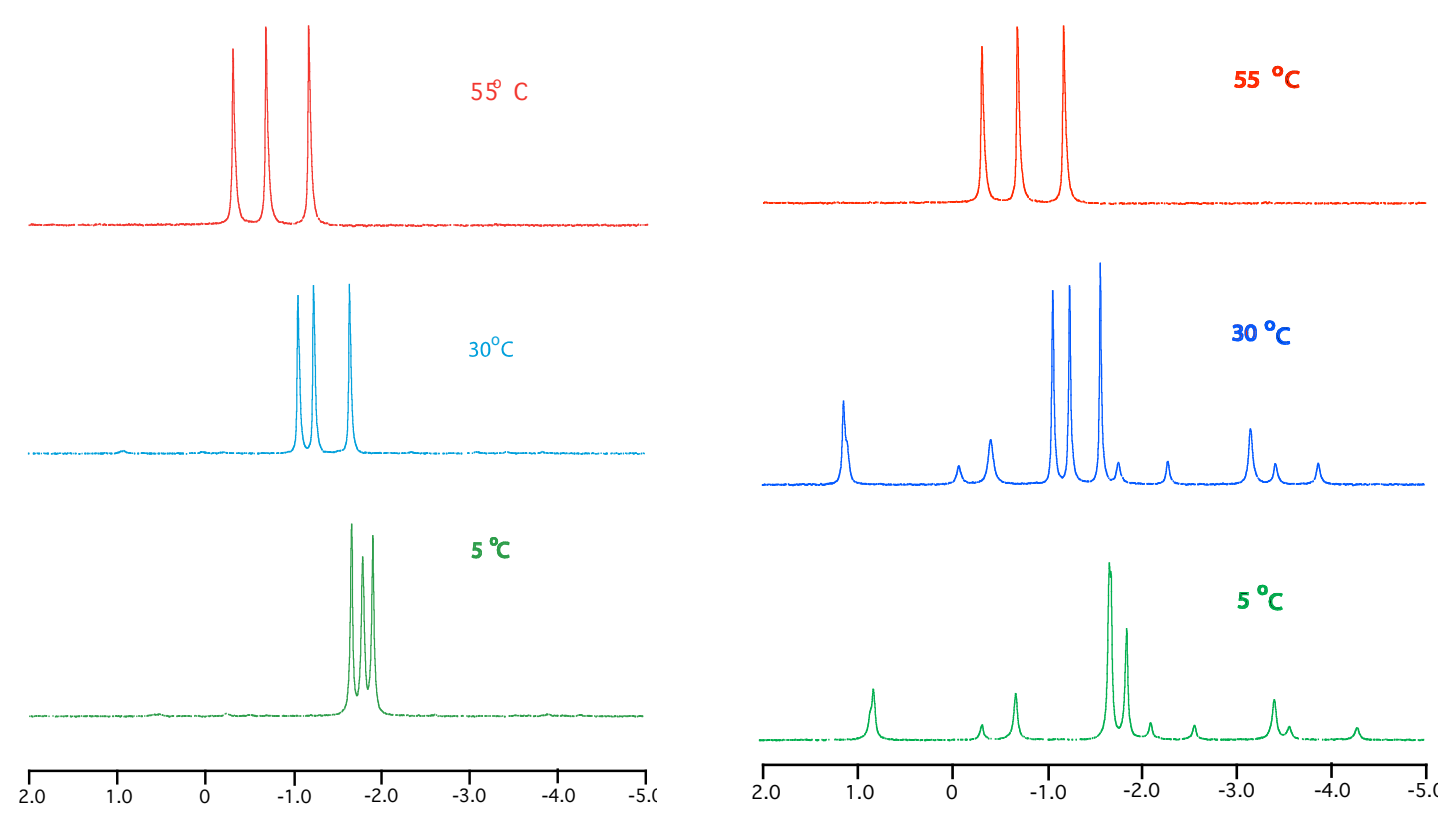

Left: $14.8 \mathrm{mM}$ 3a in 0.1M LiCl, 90/10 $\mathrm{H}_{2} \mathrm{O} / \mathrm{D}_{2} \mathrm{O}$; Right: $12.7 \mathrm{mM}$ 3a in 0.1M KCl, 90/10 $\mathrm{H}_{2} \mathrm{O} / \mathrm{D}_{2} \mathrm{O}$

\section{7b. ${ }^{1}$ H NMR Spectra of Oligoethylene Oxide Tethered c-di-GMP, 3a}
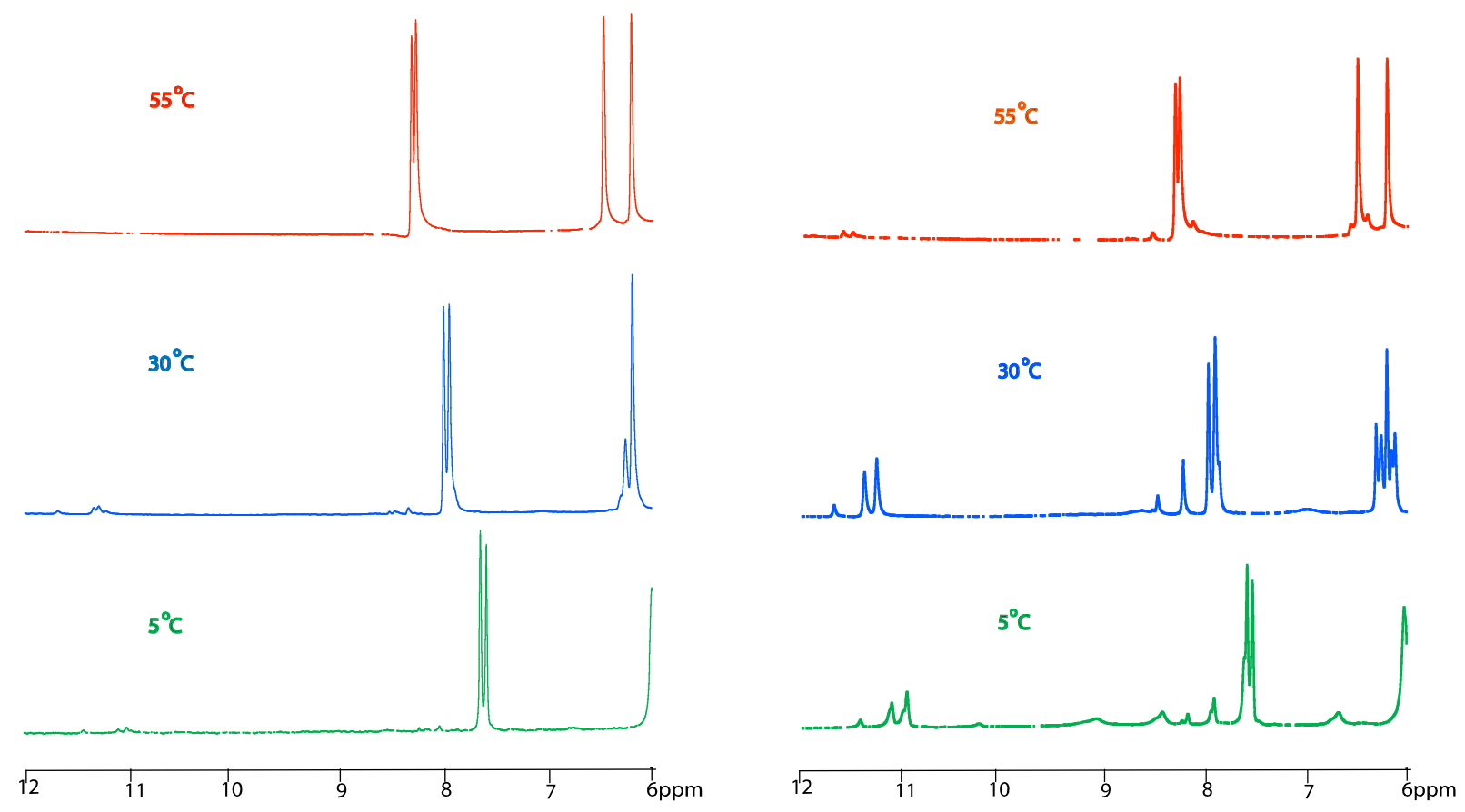

Left: 14.8 mM 3a in 0.1M LiCl, 90/10 $\mathrm{H}_{2} \mathrm{O} / \mathrm{D}_{2} \mathrm{O}$; Right: $12.7 \mathrm{mM}$ 3a in 0.1M KCl, 90/10 $\mathrm{H}_{2} \mathrm{O} / \mathrm{D}_{2} \mathrm{O}$ 


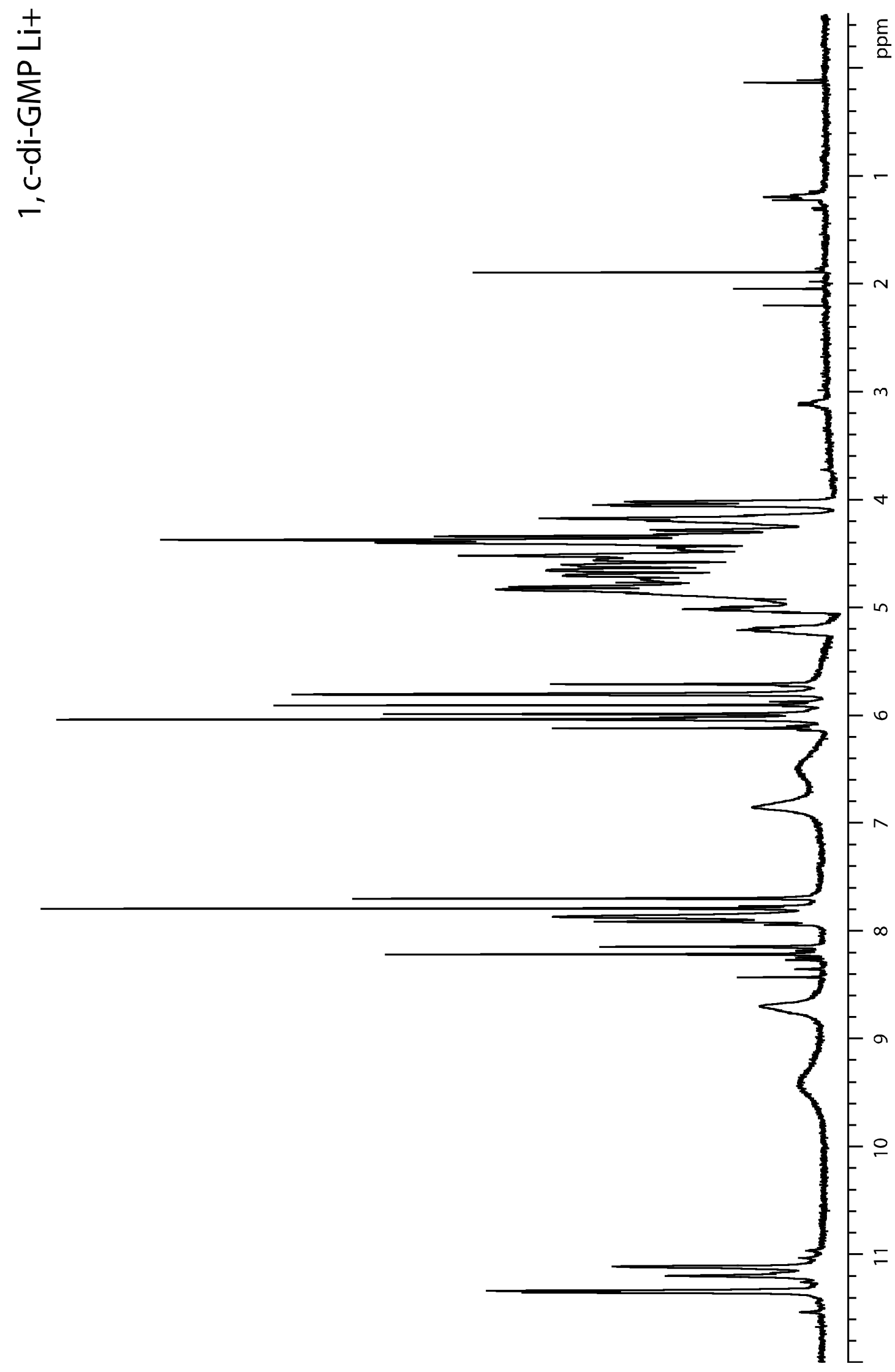

8. Full $1 \mathrm{D}{ }^{1} \mathrm{H}$ NMR of $\mathbf{1}$, c-di-GMP, $\mathrm{Li}^{+}$in $90 \% \mathrm{H}_{2} \mathrm{O}$ with water suppression at $25^{\circ} \mathrm{C}$ 


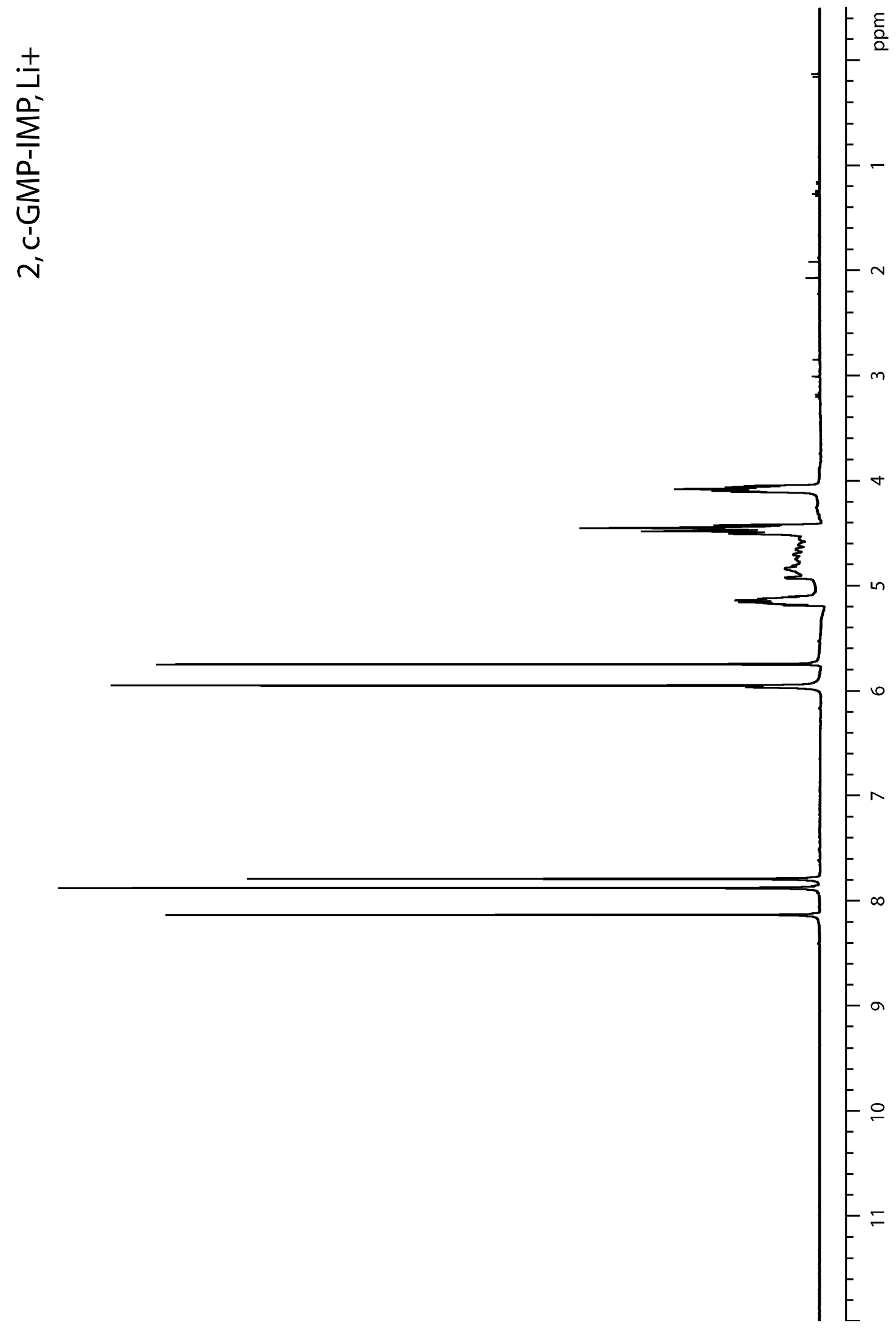

9. Full $1 \mathrm{D}{ }^{1} \mathrm{H}$ NMR of 2, c-GMP-IMP, $\mathrm{Li}^{+}$in $90 \% \mathrm{H}_{2} \mathrm{O}$ with water suppression at $25^{\circ} \mathrm{C}$ 


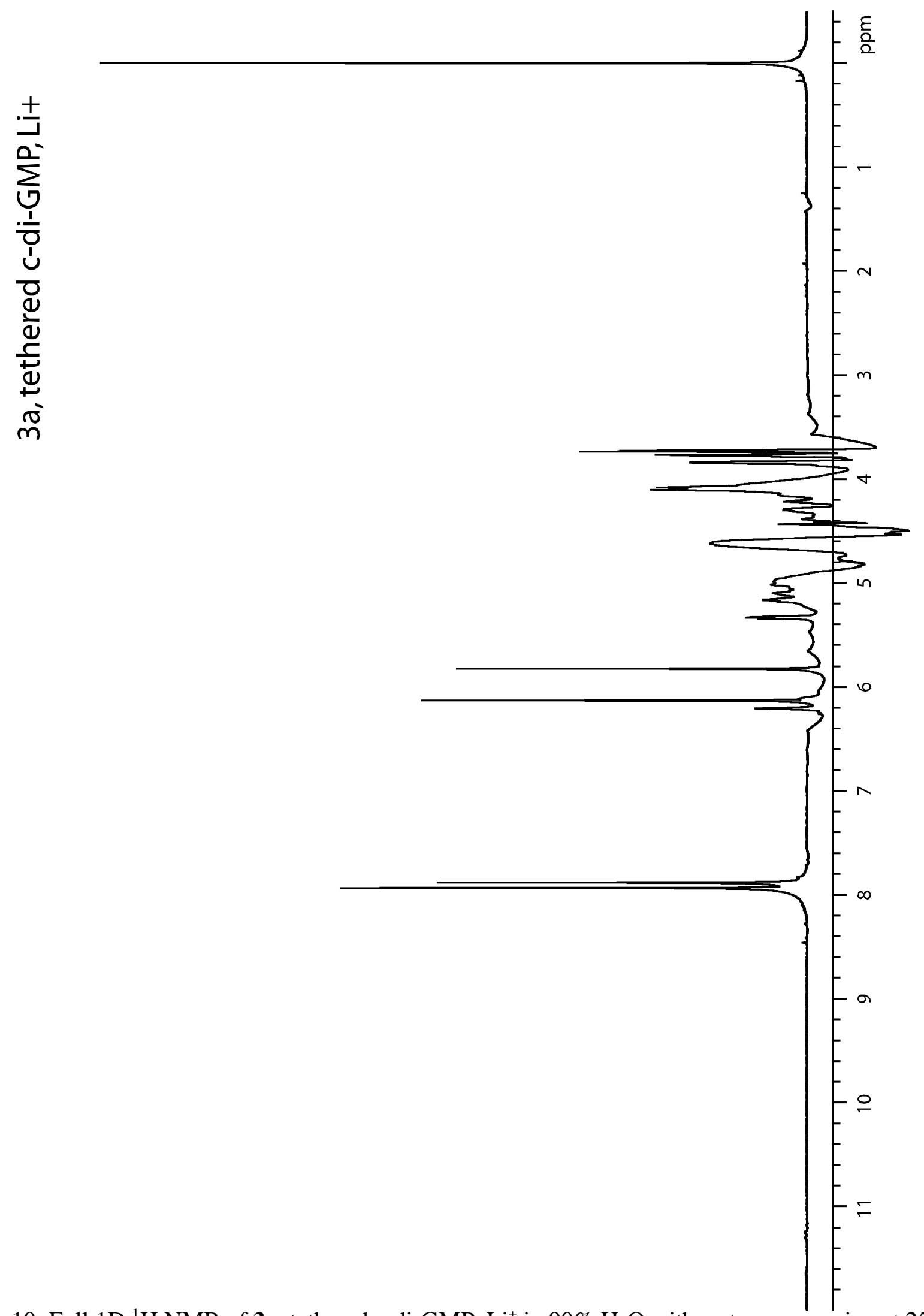

10. Full 1D ${ }^{1} \mathrm{H}$ NMR of 3a, tethered c-di-GMP, $\mathrm{Li}^{+}$in $90 \% \mathrm{H}_{2} \mathrm{O}$ with water suppression at $25^{\circ} \mathrm{C}$

(1) Serebryany, V.; Beigelman, L. Tetrahedron Lett. 2002, 43, 1983-1985.

(2) Zhang, Z.; Gaffney, B. L.; Jones, R. A. J. Am. Chem. Soc. 2004, 126, 16700-16701. 